\title{
PENGEMBANGAN LEMBAR KEGIATAN PESERTA DIDIK (LKPD) BERBASIS PREVIEW, QUESTION, READ, REFLECT, RECITE, REVIEW(PQ4R) PADA POKOK BAHASAN KESETIMBANGAN ION DAN pH LARUTAN GARAM
}

\author{
Ashry Khoirunisa ${ }^{1}$, Sri Haryati ${ }^{1}$, Radjawaly Usman Rery ${ }^{1}$ \\ 1, Universitas Riau, Jalan Bina Widya KM 12,5, Simpang Baru, Kec. Tampan, Kota Pekanbaru, \\ Riau 28293
}

\begin{abstract}
Abstrak - Penelitian bertujuan untuk menghasilkan lembar kegiatan peserta didik berbasis PQ4R pada pokok bahasan kesetimbangan ion dan $\mathrm{pH}$ larutan garam yang layak. Jenis penelitian ini adalah penelitian dan pengembangan atau research and development $(\mathrm{R} \& \mathrm{D})$ dengan model pengembangan 4-D yang meliputi Define, Design, Develop, dan Disseminate. Analisis data menggunakan analisis statistik deskriptif dengan cara menghitung persentase nilai validasi. Hasil validasi LKPD oleh 3 orang dosen sebagai tim validator ahli materi adalah 94,27\% dengan kategori layak dan telah memenuhi aspek kelayakan isi, karakteristik PQ4R, kebahasaan, penyajian dan kegrafisan. 2 orang guru dan 20 orang peserta didik memberikan respon yang positif terhadap LKPD hasil pengembangan dengan persentase penilaian berturut-turut sebesar 95,45\% dan 93,89\%. Hal ini menunjukkan bahwa LKPD yang telah dikembangkan layak digunakan dalam pembelajaran.
\end{abstract}

Kata kunci: LKPD, PQ4R, Kesetimbangan Ion dan $p H$ Larutan Garam

\begin{abstract}
The objective of this research was to develop the PQ4R-based student's activity sheet in the subject of ionic equilibrium and pH of saline solution. The type of this research was research and development (Re'v) with the 4-D development model consisting of Define, Design, Develop, and Disseminate steps. The data analysis technique was descriptive statistical analysis by calculating the percentage of validation's score. The validation score for the eligibility of the student's activity sheet given by 3 lecturers was 94,27\%. The score implies that the student's activity sheet has already fulfilled the eligibility of contents, PQ4R characteristics, language, content design and graphic. 2 teachers and 20 students gave positive responses to the student's activity sheet with the score of $95.45 \%$ and $93.89 \%$ respectively. This shows that the LKPD that has been developed is feasible to be used in chemistry instructional.
\end{abstract}

Keywords: student's activity sheet, PQ4R, ionic equilibrium and $p H$ of saline solution.

\section{PENDAHULUAN}

Pendidikan merupakan suatu kegiatan yang bertujuan untuk mengembangkan kualitas manusia. Menurut Margono (2004), pendidikan merupakan usaha untuk mengembangkan dan membina potensi sumber daya manusia melalui berbagai kegiatan belajar mengajar yang diselenggarakan pada semua jenjang pendidikan dari tingkat dasar, menengah dan perguruan tinggi.

Kegiatan belajar merupakan kegiatan paling pokok dalam keseluruhan proses pendidikan di sekolah (Slameto, 2010). Kegiatan belajar dalam pendidikan formal tidak terlepas dari proses kegiatan belajar di sekolah. Agar proses pembelajaran berjalan dengan baik, maka seorang guru selain menguasai materi, dituntut juga menguasai strategi pembelajaran yang dapat mengaktifkan peserta

\footnotetext{
${ }^{1}$ Corresponding author: Jurusan Kimia, Universitas Riau, Pekanbaru 28293, Indonesia. Email: ashrykhoirunisa7@gmail.com

ISSN 2528-6536 (print)/ISSN 2579-5945 (online) @2019 J-PEK
} 
didik dalam proses pembelajaran. Keberhasilan pencapaian tujuan pembelajaran di sekolah banyak bergantung pada bagaimana proses yang dialami peserta didik. Pembelajaran adalah suatu perubahan perilaku yang relatif tetap dan merupakan hasil praktik yang diulang-ulang. Subjek didalam pembelajaran adalah peserta didik yang menjadi pusat dari kegiatan belajar (Thobroni, 2015).

Pada saat ini, salah satu permasalahan yang sering ditemukan dalam dunia pendidikan adalah keterbatasan bahan ajar yang berfungsi untuk memfasilitasi peserta didik agar dapat membangun keaktifan dan pemahaman konsep materi pelajaran. Menurut Prastowo (2012), bahan ajar adalah seperangkat materi yang disusun secara sistematis, baik tertulis maupun tidak tertulis sehingga tercipta lingkungan atau suasana yang memungkinkan peserta didik untuk belajar. Bahan ajar yang umum digunakan oleh guru saat ini adalah Lembar Kegiatan Peserta Didik (LKPD). LKPD adalah lembaran-lembaran kertas untuk menyusun skema pemecahan masalah, mencatat data hasil pengamatan dan lembar diskusi.

Berdasarkan hasil angket yang penulis sebar kepada 85 orang peserta didik disekolah, ternyata $91,76 \%$ peserta didik menyatakan bahwa penggunaan LKPD sangat diperlukan dalam penemuan konsep pada pembelajaran kimia, 90,59\% peserta didik juga menyatakan bahwa penggunaan LKPD yang menerapkan keterampilan membaca dan bertanya pada pembelajaran kimia membuat belajar lebih menarik dan 92,9\% peserta didik menyatakan bahwa materi kesetimbangan ion dan $p \mathrm{H}$ larutan garam merupakan salah satu materi yang sulit dipahami.

Berdasarkan informasi yang diperoleh dari dua orang guru kimia SMA/MA di Pekanbaru, peserta didik masih sulit untuk mendapatkan sendiri pengetahuan dan konsep materi yang dipelajari. Dalam proses pembelajaran sudah digunakan LKPD, meskipun LKPD tersebut telah sesuai dengan indikator dan tujuan pembelajaran. Kelemahan LKPD tersebut adalah dari segi isi dan penyajiannya masih monoton, kurang menarik serta hanya berisi permasalahan dan pertanyaanpertanyaan yang harus dikerjakan peserta didik tanpa memberikan tuntunan dan bimbingan untuk menyelesaikan permasalahan. Hal tersebut menyebabkan peserta didik masih kesulitan dalam memahami konsep materi kesetimbangan ion dan $\mathrm{pH}$ larutan garam. Maka diperlukan pengembangan LKPD yang dapat menuntun peserta didik untuk mencari secara aktif, mengolah, dan membangun pengetahuannya sendiri.

PQ4R merupakan strategi pembelajaran yang dapat memusatkan peserta didik pada pengorganisasian informasi, penimbul pertanyaan, dan pendorong aktifitas tanya jawab yang bertujuan agar peserta didik dapat melakukan pengolahan materi secara lebih mendalam dan luas serta memperoleh pengetahuan yang bermakna (Darise, dkk., 2015). Pembelajaran dengan menggunakan LKPD berbasis strategi PQ4R dapat menjadikan peserta didik aktif dalam menemukan konsep sehingga pengetahuan yang diperoleh menjadi bermakna.

Langkah-langkah pembelajaran PQ4R menurut Trianto (2011) terdiri dari preview, question, read, reflect, recite dan riview. Kegiatan yang dilakukan peserta didik pada tahap preview adalah membaca selintas dengan cepat suatu wacana dan menemukan ide pokok yang terkandung di dalamnya. Pada tahap question, peserta didik mengajukan pertanyaan-pertanyaan kepada diri sendiri berdasarkan ide pokok yang telah ditemukannya. Pada tahap read, peserta didik membaca secara aktif, yakni membaca materi dengan seksama dan diminta mencari jawaban terhadap pertanyaan-pertanyaan yang diajukan sebelumnya. Pada tahap reflect, peserta didik menghubungkan materi yang telah dibacanya pada tahap read dengan wacana pada tahap preview. Kegiatan yang dilakukan peserta didik pada tahap recite adalahmerenungkan (mengingat) kembali informasi yang telah dipelajari dengan membuat rangkuman dan menjawab pertanyaan. Kegiatan pada tahap terakhir yaitu tahap review. Pada tahap ini peserta didik mengkomunikasikan hasil diskusinya.

Materi kesetimbangan ion dan $p \mathrm{H}$ larutan garam diajarkan di kelas XI SMA/MA semester genap. Kesulitan belajar terjadi pada materi kesetimbangan ion dan $p \mathrm{H}$ larutan garam dikarenakan materi bersifat abstrak dan diperlukan logika untuk menghubungkan konsep materi. Untuk 
mempermudah peserta didik dalam memahami materi kesetimbangan ion dan $p \mathrm{H}$ larutan garam dapat digunakan bahan ajar berupa LKPD berbasis PQ4R yang menarik dan dapat melatih keterampilan peserta didik dalam menemukan konsep sendiri dengan cara membaca berulang terhadap materi yang dipaparkan pada LKPD.

Hasil penelitian dan pengembangan LKPD yang dilakukan oleh Panjalin dan Ismono (2016) yang berjudul "Pengembangan Lembar Kerja Siswa (LKS) Strategi PQ4R dengan Penerapan Fill in Scaffolding pada Pokok Bahasan Ikatan Kimia" menyimpulkan LKS yang dikembangkan dinyatakan layak digunakan. Berdasarkan latar belakang yang telah diuraikan mendorong peneliti untuk melakukan penelitian tentang: "Pengembangan Lembar Kegiatan Peserta Pidik (LKPD) Berbasis Preview, Question, Read, Reflect, Recite, Review (PQ4R) pada Pokok Bahasan Kesetimbangan Ion dan pH Larutan Garam".

\section{METODE}

Penelitian dilaksanakan di Fakultas Keguruan dan Ilmu Pendidikan Program Studi Pendidikan Kimia. Jenis penelitian yang dilakukan adalah penelitian dan pengembangan (research and development) dengan proses pengembangan mengacu kepada model pengembangan 4-D yaitu Define (Pendefinisian), Design (Perancangan), Develop (Pengembangan) dan Disseminate (Penyebaran). Penelitian ini hanya dilakukan sampai tahap pengembangan dan analisis respon pengguna.

Langkah-langkah penelitian menggunakan model pengembangan 4-D menurut Trianto (2012) adalah sebagai berikut:

Tahap Define adalah tahap menetapkan dan mendefinisikan syarat-syarat penyusunan LKPD berbasis PQ4R. Terdapat 3 langkah pokok tahap ini, yaitu analisis ujung depan, analisis peserta didik, dan analisis tugas. Analisis ujung depan dimaksudkan untuk menentukan masalah yang menjadi dasar dalam pembelajaran yang perlu diangkat dalam pengembangan LKPD. Analisis peserta didik dilakukan untuk mengetahui pada kelas berapa penelitian ini ditujukan. Analisis tugas terbagi menjadi 4 langkah yaitu analisis struktur isi untuk menentukan isi materi yang akan diangkat, analisis konsep untuk mengidentifikasi konsep-konsep utama yang akan diajarkan, analisis prosedural untuk mengidentifikasi tahap-tahap penyelesaian tugas, dan analisis tujuan pembelajaran untuk merumuskan tujuan pembelajaran yang akan dicapai.

Tahap Design dikenal juga dengan istilah membuat rancangan. Pada tahap ini, peneliti akan membuat rancangan LKPD yang memenuhi kriteria kelayakan LKPD. Format LKPD yang dikembangkan adalah LKPD berbasis strategi $P Q 4 \mathrm{R}$ pada materi Kesetimbangan Ion dan $p \mathrm{H}$ Larutan Garam.

Tahap Develop (pengembangan), LKPD yang telah dikembangkan kemudian divalidasi oleh validator ahli materi berfungsi untuk memvalidasi konten materi kimia yang akan ditampilkan dalam LKPD dan penilaian respon pengguna yang bertujuan untuk mengetahui kriteria respon guru dan peserta didik terhadap LKPD yang dikembangkan.

Instrumen pengumpulan data yang digunakan adalah lembar validasi yang diberikan kepada 3 orang validator ahli materi dan lembar respon guru sebagai pengguna sebanyak 2 orang dan peserta didik sebanyak 20 orang.

Teknik analisis data yang digunakan dalam penelitian adalah analisis deskriptif, yakni dengan cara menghitung rata-rata dari setiap aspek penilaian yang terdapat pada masing-masing aspek pada lembar validasi LKPD berbasis PQ4R pada pokok bahasan kesetimbangan ion dan $\mathrm{pH}$ larutan garam. Rumus yang digunakan untuk menentukan kategori rata-rata dari setiap aspek yang terdapat pada lembar validasi sebagai berikut:

$$
\text { Persentase }=\frac{\text { Skor yang diperoleh }}{\text { Skor maksimum }} \times 100 \%
$$


Tingkat kelayakan produk hasil penelitian pengembangan diidentikkan dengan persentase skor. Semakin besar persentase skor hasil analisis data maka semakin baik tingkat kelayakan produk hasil penelitian pengembangan. Kriteria dalam mengambil keputusan dalam validasi LKPD dapat dilihat pada Tabel 1.

Tabel 1. Kriteria Validitas

\begin{tabular}{cc}
\hline Persentase & Keterangan \\
\hline $80,00-100$ & Baik/Valid/Layak \\
$60,00-79,99$ & Cukup Baik/Cukup Valid/Cukup Layak \\
$50,00-59,99$ & Kurang baik/Kurang Valid/Kurang Layak \\
$0-49,99$ & Tidak Baik (diganti) \\
\hline
\end{tabular}

(Riduwan, 2012)

Data hasil analisis respon pengguna dianalisis sesuai dengan pedoman penilaian yang telah dikembangkan. Lembar tanggapan guru dan peserta didik disusun berdasarkan skala Guttman, dimana skala ini hanya memiliki dua interval, yaitu "setuju" dan "tidak setuju" atau "ya" dan "tidak". Jawaban positif diberi nilai 1 dan 0 untuk jawaban negatif. Kriteria respon/tanggapan yang digunakan seperti pada Tabel 2.

Tabel 2. Kriteria Respon Pengguna

\begin{tabular}{cc}
\hline Persentase & Kriteria Respon Pengguna \\
\hline$\geq 85 \%$ & Positif \\
$\geq 70 \%$ & Cukup Positif \\
$\geq 50 \%$ & Kurang Positif \\
$\leq 50 \%$ & Tidak Positif \\
\hline
\end{tabular}

(Yamasari, 2010)

\section{HASIL DAN PEMBAHASAN}

Produk yang dihasilkan dari penelitian dan pengembangan ini adalah LKPD dengan langkahlangkah penyelesaian tugas menggunakan tahapan PQ4R yaitu preview, question, read, reflect, recite, dan review pada pembelajaran kimia pokok bahasan kesetimbangan ion dan $\mathrm{pH}$ larutan garam. Tahaptahap penelitian pengembangan LKPD meliputi tahap Define, tahap Design dan tahap Develop.

Tahap Define meliputi 3 langkah pokok, yaitu analisis ujung depan, analisis peserta didik, dan analisis tugas. Hasil analisis ujung depan yaitu masih terbatasnya Lembar Kegiatan Peserta Didik (LKPD) yang dapat memfasilitasi peserta didik dalam memahami konsep kesetimbangan ion dan $\mathrm{pH}$ larutan garam sehingga diperlukan pengembangan LKPD berbasis PQ4R pada pokok bahasan kesetimbangan ion dan $\mathrm{pH}$ larutan garam. Analisis peserta didik menunjukkan bahwa peserta didik atau pengguna produk LKPD Kesetimbangan ion dan $\mathrm{pH}$ larutan garam adalah peserta didik kelas XI IPA SMA/MA yang memiliki rentang usia 16-17 tahun. Analisis tugas menghasilkan beberapa analisis, diantaranya analisis struktur isi, analisis konsep, analisis prosedural, dan perumusan tujuan pembelajaran.

Tahap Design menghasilkan rancangan awal LKPD dan lembar validasi LKPD. Rancangan LKPD yang dikembangkan memuat struktur LKPD sesuai dengan Panduan Pengembangan Bahan Ajar (Depdiknas, 2008) yang meliputi judul LKPD, petunjuk LKPD, materi LKPD dan aktivitas peserta didik. Aktivitas peserta didik dalam LKPD menggunakan tahapan PQ4R yang terdiri dari tahap preview, question, read, reflect, recite, dan review.

Menurut Trianto (2011) tahapan dalam strategi PQ4R sebagai berikut:

a) Preview, langkah ini dimaksudkan agar peserta didik membaca selintas dengan cepat suatu wacana dan menemukan ide pokok yang terkandung di dalamnya.

b) Question, langkah kedua adalah mengajukan pertanyaan-pertanyaan kepada diri sendiri berdasarkan ide pokok yang telah ditemukannya. 
c) Read, membaca secara aktif, yakni peserta didik diminta membaca materi dengan seksama dan diminta mencari jawaban terhadap pertanyaan-pertanyaan yang diajukan sebelumnya.

d) Reflect, langkah ini dimaksudkan agar peserta didik menghubungkan materi yang telah dibacanya pada tahap read dengan wacana pada tahap preview.

e) Recite, peserta didik diminta untuk merenungkan (mengingat) kembali informasi yang telah dipelajari dengan membuat rangkuman dan menjawab pertanyaan-pertanyaan.

f) Review, langkah terakhir ini peserta didik diminta untuk mengkomunikasikan hasil diskusinya.

Tahap Develop menghasilkan rancangan LKPD, yaitu Lembar Kegiatan Peserta Didik berbasis PQ4R pada pokok bahasan Kesetimbangan ion dan $\mathrm{pH}$ larutan garam. Produk rancangan awal LKPD dikonsultasikan kepada dosen pembimbing agar mendapat masukan untuk pengembangan dan perbaikan LKPD sebelum dilakukan validasi. Validasi LKPD bertujuan untuk mengetahui kelayakan LKPD yang akan digunakan dalam kegiatan pembelajaran. Validasi LKPD dilakukan oleh 3 orang validator ahli materi. Validasi LKPD meliputi 5 aspek, yaitu aspek kelayakan isi, karakteristik PQ4R, kebahasaan, penyajian dan kegrafisan.

Rekap skor rata-rata penilaian kelima aspek kelayakan LKPD yang dinilai oleh 3 validator ahli materi dapat dilihat pada Tabel 3.

Tabel 3. Rekap Skor Rata-rata Penilaian Kelima Aspek Kelayakan LKPD

\begin{tabular}{|c|c|c|c|c|c|c|}
\hline No & $\begin{array}{c}\text { Aspek yang } \\
\text { dinilai }\end{array}$ & $\begin{array}{c}\text { Skor } \\
\text { Rata-rata } \\
\text { Validator 1 }\end{array}$ & $\begin{array}{c}\text { Skor } \\
\text { Rata-rata } \\
\text { Validator } 2\end{array}$ & $\begin{array}{c}\text { Skor } \\
\text { Rata-rata } \\
\text { Validator } 3\end{array}$ & $\begin{array}{l}\text { Skor Rata- } \\
\text { Rata Validasi }\end{array}$ & Ket \\
\hline 1 & Kelayakan isi & $85,71 \%$ & $92,86 \%$ & $100 \%$ & $92,86 \%$ & Layak \\
\hline 2 & $\begin{array}{c}\text { Kelayakan } \\
\text { Karakteristik } \\
\text { PQ4R }\end{array}$ & $96,43 \%$ & $92,86 \%$ & $92,86 \%$ & $94,05 \%$ & Layak \\
\hline 3 & $\begin{array}{l}\text { Kelayakan } \\
\text { Kebahasaan }\end{array}$ & $100 \%$ & $100 \%$ & $95 \%$ & $98,33 \%$ & Layak \\
\hline 4 & $\begin{array}{l}\text { Kelayakan } \\
\text { penyajian }\end{array}$ & $91,66 \%$ & $100 \%$ & $91,66 \%$ & $94,44 \%$ & Layak \\
\hline 5 & $\begin{array}{l}\text { Kelayakan } \\
\text { kegrafisan }\end{array}$ & $93,75 \%$ & $87,50 \%$ & $93,75 \%$ & $91,67 \%$ & Layak \\
\hline \multicolumn{5}{|c|}{ Skor rata-rata keseluruhan validasi } & $94,27 \%$ & Layak \\
\hline
\end{tabular}

Berdasarkan kriteria validitas menurut Riduwan (2012) pada Tabel 1, hasil validasi dengan skor 80 - 100 termasuk ke dalam kategori layak. LKPD kesetimbangan ion dan $\mathrm{pH}$ larutan garam berbasis PQ4R dinyatakan layak setelah dilakukan perbaikan berdasarkan saran yang diberikan validator saat dilakukan proses validasi.

LKPD yang dinyatakan layak oleh validator kemudian dilakukan analisis respon pengguna kepada guru dan peserta didik. Tahap analisis respon pengguna dilakukan di SMA Negeri 1 Pekanbaru dan SMAN 9 Pekanbaru dengan jumlah responden guru kimia sebanyak 2 orang dan responden peserta didik sebanyak 20 orang. Peserta didik sebelumnya telah mempelajari materi kesetimbangan ion dan $\mathrm{pH}$ larutan garam, sehingga diharapkan dapat memberi masukan untuk menilai dan memberi saran perbaikan LKPD karena telah memiliki pengetahuan dasar tentang materi. 
Hasil rata-rata tanggapan/respon guru terhadap LKPD berbasis PQ4R adalah 95,45\%. Menurut Yamasari (2010) pada tabel 2, kriteria respon pengguna dengan persentase $\geq 85 \%$ adalah positif. Hasil respon guru terhadap LKPD disajikan dalam Tabel 4.

Tabel 4. Hasil Respon Guru terhadap LKPD Berbasis PQ4R

\begin{tabular}{|c|c|c|c|}
\hline No & Pernyataan & Persentase & Kriteria \\
\hline 1 & $\begin{array}{l}\text { LKPD membantu peserta didik memahami materi Kesetimbangan } \\
\text { Ion dan pH Larutan Garam dalam proses pembelajaran }\end{array}$ & $100 \%$ & Positif \\
\hline 2 & $\begin{array}{c}\text { Bahasa yang digunakan dalam LKPD Kimia komunikatif sehingga } \\
\text { memudahkan peserta didik dalam memahami materi Kesetimbangan } \\
\text { Ion dan pH Larutan Garam }\end{array}$ & $100 \%$ & Positif \\
\hline 3 & Desain, penulisan dan gambar dalam LKPD terlihat menarik & $100 \%$ & Positif \\
\hline 4 & $\begin{array}{l}\text { Langkah-langkah bimbingan yang diberikan dalam LKPD jelas dan } \\
\text { mudah dimengerti }\end{array}$ & $100 \%$ & Positif \\
\hline 5 & $\begin{array}{c}\text { LKPD membimbing peserta didik untuk berkreativitas dalam } \\
\text { mengerjakan latihan yang ada didalam LKPD }\end{array}$ & $100 \%$ & Positif \\
\hline 6 & $\begin{array}{l}\text { LKPD mendorong peserta didik untuk mengutarakan ide-idenya pada } \\
\text { saat berdiskusi }\end{array}$ & $50 \%$ & Kurang Positif \\
\hline 7 & $\begin{array}{l}\text { LKPD berbasis } P Q 4 R \text { menuntut peserta didik untuk selalu aktif } \\
\text { sehingga pembelajaran tidak hanya berpusat pada guru }\end{array}$ & $100 \%$ & Positif \\
\hline 8 & $\begin{array}{l}\text { Kalimat yang digunakan dalam LKPD dapat dibaca dengan jelas, } \\
\text { terstruktur dan tidak menimbulkan makna ganda }\end{array}$ & $100 \%$ & Positif \\
\hline 9 & $\begin{array}{c}\text { Penyajian LKPD sangat menarik dan membuat peserta didik lebih } \\
\text { bersemangat dalam belajar Kimia }\end{array}$ & $100 \%$ & Positif \\
\hline 10 & $\begin{array}{c}\text { LKPD membangun pengetahuan peserta didik sedikit demi sedikit } \\
\text { sehingga peserta didik menjadi paham terhadap materi yang } \\
\text { disampaikan }\end{array}$ & $100 \%$ & Positif \\
\hline \multirow[t]{2}{*}{11} & $\begin{array}{c}\text { Penyampaian materi dalam LKPD disesuaikan dengan kemampuan } \\
\text { peserta didik sebelumnya sehingga memudahkan peserta didik untuk } \\
\text { memahami materi yang disampaikan }\end{array}$ & $100 \%$ & Positif \\
\hline & Skor rata-rata & $95,45 \%$ & Positif \\
\hline
\end{tabular}

Hasil rata-rata respon peserta didik pada analisis respon pengguna terhadap LKPD berbasis PQ4R adalah 93,89\%. Menurut Yamasari (2010) pada Tabel 2, kriteria respon pengguna dengan persentase $\geq 85 \%$ adalah positif. Hasil respon peserta didik terhadap LKPD disajikan dalam Tabel 5.

Berdasarkan hasil analisis respon pengguna yang dilakukan kepada guru kimia dan peserta didik, LKPD berbasis PQ4R yang dikembangkan sudah baik, bahasa yang digunakan jelas dan mudah dipahami, tampilannya menarik karena ada ilustrasi gambar dan warnanya yang cerah serta dapat membantu dalam memahami materi dengan baik.

Tabel 5. Hasil Respon Peserta Didik terhadap LKPD Berbasis PQ4R

\begin{tabular}{|c|c|c|c|}
\hline No & Pernyataan & Persentase & Kriteria \\
\hline 1 & $\begin{array}{l}\text { LKPD berbasis } P Q 4 R \text { pada materi Kesetimbangan Ion dan } \mathrm{pH} \\
\text { Larutan Garam membangun pengetahuan saya sedikit demi sedikit di } \\
\text { tiap sub materinya sehingga saya menjadi benar-benar paham }\end{array}$ & $100 \%$ & Positif \\
\hline 2 & $\begin{array}{c}\text { Penyampaian materi dalam LKPD sesuai dengan kemampuan saya } \\
\text { sebelumnya sehingga memudahkan saya untuk memahami materi yang } \\
\text { disampaikan }\end{array}$ & $90 \%$ & Positif \\
\hline 3 & $\begin{array}{c}\text { LKPD berbasis } P Q 4 R \text { menuntut saya untuk membaca dan mencari } \\
\text { sendiri jawaban atas pertanyaan saya sehingga pembelajaran tidak } \\
\text { berpusat pada guru }\end{array}$ & $80 \%$ & Positif \\
\hline 4 & $\begin{array}{c}\text { Langkah-langkah bimbingan yang diberikan dalam LKPD ini jelas dan } \\
\text { mudah dimengerti }\end{array}$ & $90 \%$ & Positif \\
\hline 5 & Saya mendapat informasi yang jelas dari LKPD berbasis $P Q 4 R$ ini & $100 \%$ & Positif \\
\hline
\end{tabular}




\begin{tabular}{cccc}
\hline 6 & $\begin{array}{c}\text { Bahasa yang digunakan dalam LKPD berbasis PQ4R mudah dipahami } \\
\text { sehingga memudahkan saya dalam memahami materi Kesetimbangan } \\
\text { Ion dan pH Larutan Garam }\end{array}$ & $90 \%$ & Positif \\
7 & Tampilan dan penyajian LKPD sangat menarik & $100 \%$ & Positif \\
8 & LKPD yang digunakan lebih menarik daripada LKPD yang biasanya & $100 \%$ & Positif \\
sehingga saya lebih bersemangat ketika mengerjakan soal & Positif \\
\hline & Saya merasa pembelajaran kimia akan lebih menarik jika menggunakan & $95 \%$ & PKPD berbasis PQ4R \\
\hline
\end{tabular}

Secara keseluruhan LKPD berbasis PQ4R pada pokok bahasan kesetimbangan ion dan $\mathrm{pH}$ larutan garam yang dikembangkan telah memenuhi kriteria kelayakan dari aspek kelayakan isi, kelayakan karakteristik PQ4R, kelayakan bahasa, kelayakan penyajian, dan kelayakan grafis sehingga layak untuk digunakan dalam proses pembelajaran disekolah.

\section{KESIMPULAN}

Berdasarkan hasil penelitian, analisis pengolahan data dan pembahasan dapat disimpulkan bahwa pengembangan LKPD berbasis PQ4R pada pokok bahasan kesetimbangan ion dan pH larutan garam dapat dilakukan dengan menggunakan desain penelitian dan pengembangan dengan model 4-D. LKPD hasil pengembangan divalidasi dan dinyatakan telah memenuhi aspek kelayakan isi, karakteristik PQ4R, kebahasaan, sajian dan kegrafisan dengan persentase kelayakan berturut-turut sebesar $92,86 \%, 94,05 \%, 98,33 \%, 94,44 \%$, dan $91,67 \%$ dan diperoleh rata-rata sebesar $94,27 \%$ dengan kategori layak. Respon guru dan peserta didik terhadap LKPD kesetimbangan ion dan $\mathrm{pH}$ garam berbasis PQ4R berturut-turut adalah 95,45\% dan 93,89\% dengan kriteria positif, sehingga LKPD yang telah dikembangkan layak digunakan dalam proses pembelajaran.

\section{DAFTAR RUJUKAN}

Darise, I.W., Idris, H. dan Mutmainah. (2015). Pengaruh Penerapan Strategi Pembelajaran PQ4R Terhadap Prestasi Belajar Peserta Didik pada Mata Pelajaran SKI (Sejarah Kebudayaan Islam) di MTs Negeri Unggulan Manado. Jurnal Pendidikan Islam Iqra' 9 (1): 35-61. Manado: Fakultas Tarbiyah dan Ilmu Keguruan IAIN Manado

Depdiknas. (2008). Pengembangan Bahan Ajar. Jakarta: Departemen Pendidikan Nasional

Margono. (2004). Metodologi Penelitian Pendidikan. Jakarta: PT Rineka Cipta

Panjalin, A.N dan Ismono. (2016). Pengembangan LKS Strategi PQ4R dengan Penerapan Fill In Scaffolding untuk Mengetahui Aktivitas dan Hasil Belajar Peserta Didik pada Materi Ikatan Kimia. Jurnal Pendidikan Kimia UNESA (5)3: 614-620. Surabaya: Universitas Negeri Surabaya

Prastowo, A. (2012). Panduan Kreatif Membuat Bahan Ajar Inovatif. Yogyakarta: Diva Press

Riduwan. (2012). Skala Pengukuran Variabel-variabel Penelitian. Bandung: Alfabeta

Slameto. (2010). Belajar dan Faktor yang Mempengarubinya. Jakarta: Rineka Cipta

Thobroni, M. (2015). Belajar dan Pembelajaran. Yogyakarta: Ar-ruzz Media

Trianto. (2011). Mendesain Model Pembelajaran Inovatif-Progresif. Jakarta: Kencana Prenada Media Group

Trianto. (2012). Model Pembelajaran Terpadu. Jakarta: Bumi Aksara

Yamasari, Y. (2010). Pengembangan Media Pembelajaran Matematika Berbasis ICT yang Berkualitas. Seminar Nasional Pascasarjana X-ITS ISBN No. 979-545-0270-1. Surabaya: FMIPA UNESA 